Original Article

\title{
ISOLATION OF PHYTOCONSTITUENT, IN VITRO ANTICANCER STUDY IN HELA AND MCF-7 CELL LINES AND MOLECULAR DOCKING STUDIES OF POTHOS SCANDENS LINN
}

\author{
SEEMA S. NAIR ${ }^{1}$, JOYAMMA VARKEY ${ }^{2}$ \\ 1,2Government Medical College, Thiruvananthapuram, Kerala 695011 \\ Email: seema.s.nair@gmail.com
}

Received: 04 May 2021, Revised and Accepted: 02 Jul 2021

\begin{abstract}
Objective: This study aims to isolate an active phytoconstituent from ethanolic leaf extract of Pothos scandens Linn., to evaluate in vitro anticancer activity, and to carry out molecular docking studies of the isolated phytoconstituent.

Methods: The bioactive constituent 1,1'-(4,5-dihydroxy benzene-1,2-diyl) bisoct-7-en-1-one, a phenolic compound, was isolated by using chromatographic methods and the structure was elucidated by various spectroscopic techniques. In vitro anticancer activity was evaluated against HeLa and MCF 7 cell lines. The viability of cells was evaluated by direct observation of cells by an Inverted phase-contrast microscope and by the MTT assay method. IC $_{50}$ was calculated using the linear regression model.

Results: The results of anticancer studies revealed that different concentrations of the ethanolic extract of leaves of Pothos scandens Linn. exhibited cytotoxic activity against HeLa and MCF 7 cell lines with $\mathrm{IC}_{50}$ of 22.9 and $18.32 \mu \mathrm{g} / \mathrm{ml}$, respectively. The anticancer potential of the plant was revalidated by in silico molecular docking study with Vascular Endothelial Growth Factor Receptor 2 (VEGFR2, PDB ID: 4AG8) using Discovery studio 2018. Results of the docking study showed that the ligand exhibited strong interaction with the VEGFR2 kinase with significant binding energy.
\end{abstract}

Conclusion: Pothos scandens linn. can be used for the isolation of potent anticancer agents.

Keywords: Pothos scandens, Phytoconstituent, Anticancer, MTT assay, Molecular docking

(C) 2021 The Authors. Published by Innovare Academic Sciences Pvt Ltd. This is an open-access article under the CC BY license (https://creativecommons.org/licenses/by/4.0/) DOI: https://dx.doi.org/10.22159/ijcpr.2021v13i5.1882 Journal homepage: https://innovareacademics.in/journals/index.php/ijcpr

\section{INTRODUCTION}

Cancer is a disease in which some cells of our body grow abnormally and invade other parts of the body. According to WHO, 9.6 million people worldwide are estimated to have died from cancer in 2018. Globally one out of six deaths is due to cancer (WHO, 2018). Cancer may be developed due to changes in genes that control the growth and functions of our cells (National Cancer Institute, 2007). In a cancer cell, the normal cell cycle control is disrupted by: Abnormal growth factor function, Abnormal cyclin-dependent kinase (CDK) function, Abnormal DNA synthesis, and Abnormal decreases in negative regulatory forces due to mutation in the tumour suppressor gene [1].

Anticancer agents are used for curing cancer or to prolong life or reduce symptoms associated with cancer [2]. Most anticancer agents act by affecting the process of cell division. A major limitation of commonly used anticancer agents is that they also target rapidly dividing normal cells such as hair follicle cells, bone marrow cells, digestive tract cells, etc and cause harmful side effects such as bone marrow suppression, alopecia, damage to GI mucosa, and ulceration, teratogenicity, etc [3]. Plant-derived natural products have a significant role in ameliorating many diseases of human beings. The plant-based therapeutics provide an alternative strategy for better and less toxic cancer treatment [4]. Secondary plant metabolites such as alkaloids, flavonoids, polyphenols, saponins, lignans, volatile oils, terpenes, etc exhibit significant anticancer effects either by inhibiting cancer cell-activating proteins, enzymes and modulating multiple signaling pathways such as CDK2, NF- $\kappa \mathrm{B}, \mathrm{Bcl}-2$, cytokines, PI3K, Akt, MAPK/ERK, MMP, or by activating DNA repair mechanism [5-7].

P. scandens Linn. is a medicinal aroid that belongs to the family Araceae. The plant is widely distributed in Madagascar, the Himalayas, as well as Indo Burma region and Indochina [8, 9]. This plant is widely used throughout the world to cure various diseases $[10,11]$. The stem of the plant is cut up and smoked with camphor, like tobacco, for the treatment of asthma [12]. The root of the plant cut and fried in oil is used to promote the healing of abscesses. The people of Northeast India use the whole plant for bone fracture [13].
The Kanikkar tribes of Southern Western Ghats of India use P. scandens leaves mixed with the fruits of Capsicum annum and rhizome of Allium sativum and the mixture is ground into a paste with coconut oil and applied topically to heal wounds created during delivery [14]. Chinese people use the plant as a blood coagulant [15].

Despite its traditional medicinal claim, extensive research on $\mathrm{P}$. Scandens Linn. has not yet been conducted. Only a few reports are there regarding the pharmacological activities of the plant. The leaf extract of the plant was reported to possess anti-diabetic, bronchodilator [16], antibacterial, anthelmintic and larvicidal activity [17]. Various extracts of root, stem, and leaves of Pothos scandens Linn. were found to possess antioxidant and antipyretic activities [18].

\section{MATERIALS AND METHODS}

\section{Authentication and collection of plant material}

The plant Pothos scandens $L$ was identified and authenticated by Dr. G. Valsaladevi, Curator, Department of Botany, University of Kerala, Kariavattom, and the plant specimen was deposited in the Herbarium of Department of Botany, the University of Kerala, Kariavattom with voucher No. KUBH-6029.

Fresh plants of Pothos scandens L. were collected from Tropical Botanic Garden and Research Institute, Palode, Thiruvanthapuram District (Kerala) during October. The collected plant material was washed thoroughly with tap water; the leaves were cut into small pieces and air-dried under shade at room temperature for two weeks. The shade-dried leaves were powdered into a coarse powder.

\section{Preparation of extract}

About 500g of the dried leaf powder of Pothos scandens Linn. was defatted with petroleum ether $\left(60-80{ }^{\circ} \mathrm{C}\right)$ by continuous hot extraction in a soxhlet apparatus for $12 \mathrm{~h}$ [19]. The defatted powder material was extracted with $300 \mathrm{ml}$ ethyl alcohol (95\% v/v) for $48 \mathrm{~h}$ in soxhlet apparatus. The extract obtained was filtered and made solvent-free by using a rotary evaporator and the resulting semisolid mass was dried. 


\section{Isolation and structure elucidation of phytoconstituent}

About 15g of ethanolic extract was chromatographed on a silica gel column. Gradient elution was carried out with n-Hexane: Ethyl acetate (100:0-0:100) and with Ethyl acetate: Methanol (9:1). Seven fractions were collected. Each fraction was subjected to analytical TLC and those fractions with the same Rf value were pooled together. The purity of the fractions was further assessed by HPLC analysis on a C18 analytical column using Methanol: Water (65:35) as a mobile phase with a flow rate of $0.6 \mathrm{ml} / \mathrm{min}$. The column was maintained at $40{ }^{\circ} \mathrm{C}$. The purest fraction obtained was then subjected to IR, NMR, and GC-MS analysis to establish the chemical structure of the isolated compound $[20,21]$.

\section{In vitro evaluation of anti-cancer activity}

Ethanolic extract of leaves of Pothos scandens Linn. was subjected to in vitro anticancer evaluation against HeLa (cervical cancer) and MCF 7 (hormone-dependent breast cancer) cell lines. HeLa cell lines and MCF 7 cell lines were acquired from National Centre for Cell Sciences (NCCS), Pune, India, and maintained in Dulbecco's Modified Eagle Medium (DMEM, Himedia). The cell lines were cultured in a 25 $\mathrm{cm} 2$ tissue culture flask containing DMEM supplemented with $10 \%$ Fetal Bovine Serum (FBS), L-glutamine, sodium bicarbonate, and an antibiotic solution containing Penicillin $(100 \mathrm{U} / \mathrm{ml})$, Streptomycin $(100 \mu \mathrm{g} / \mathrm{ml})$, and Amphotericin B $(2.5 \mu \mathrm{g} / \mathrm{ml})$. All cell lines were cultured in a humidified incubator at $37^{\circ} \mathrm{C}$ and $5 \% \mathrm{CO} 2$ atmosphere (Galaxy® 170 Eppendorf, Germany).

The viability of cells was evaluated by direct observation of cells by an Inverted phase-contrast microscope [22] and followed by the MTT assay method $[23,24]$.

Different dilutions $(6.25 \mu \mathrm{g}, 12.5 \mu \mathrm{g}, 25 \mu \mathrm{g}, 50 \mu \mathrm{g}$ and $100 \mu \mathrm{g} / \mathrm{ml})$ of the leaf extract were prepared by adding $95 \%$ ethanol to the extract. Positive control was prepared by using doxorubicin in $95 \%$ ethanol. Test media was prepared by adding $1 \%(\mathrm{v} / \mathrm{v})$ of the various dilutions to DMEM and dissolved completely by cyclomixer. After that, the extract solutions were filtered through a $0.22 \mu \mathrm{m}$ millipore syringe filter to ensure sterility. The test results were compared with positive control containing $1 \%(\mathrm{v} / \mathrm{v})$ doxorubicin in DMEM and negative control containing $1 \%(\mathrm{v} / \mathrm{v})$ 95\% ethanol in DMEM.

Two days old confluent monolayer of cells were trypsinized and the cells were suspended in a $10 \%$ growth medium. $100 \mu \mathrm{l}$ of cell suspension (5x104 cells $/ \mathrm{ml})$ was seeded into each well of a 96 well tissue culture plate and incubated at $37^{\circ} \mathrm{C}$ in a humidified $5 \% \mathrm{CO}_{2}$ incubator.

After $24 \mathrm{~h}$ the growth medium was aspirated and replaced with 100 $\mu \mathrm{l}$ of control or test medium. Each concentration was added in triplicates to the respective wells and incubated at $37{ }^{\circ} \mathrm{C}$ in a humidified $5 \% \mathrm{CO}_{2}$ incubator $[25,26]$.

\section{Antiproliferative effect by direct microscopic observation}

The entire plate was observed at an interval of every $24 \mathrm{~h}$; up to $72 \mathrm{~h}$ in an inverted phase-contrast tissue culture microscope (Labomed TCM-400 with MICAPSTM HD camera) and microscopic observations were recorded as images. Any detectable change in the morphology of the cells, such as rounding or shrinking of cells, granulation, and vacuolization in the cytoplasm of the cells, were considered as indicators of cytotoxicity.

\section{Antiproliferative effect by MTT method}

Fifteen mg of MTT (3-(4,5-dimethylthiazol-2-yl)-2,5-diphenyl tetrazolium bromide, Himedia, M-5655) was reconstituted in $3 \mathrm{ml}$ phosphate-buffered saline (PBS) until completely dissolved and sterilized by filter sterilization. After $24 \mathrm{~h}$ of the incubation period, the media in wells were removed and $20 \mu \mathrm{l}$ of reconstituted MTT solution was added to all test and control wells; the plate was gently shaken and then incubated at $37^{\circ} \mathrm{C}$ in a humidified $5 \% \mathrm{CO} 2$ incubator for $4 \mathrm{~h}$. After the incubation period, the supernatant was removed and $100 \mu$ DMSO was added to all wells and mixed thoroughly to dissolve dark blue formazan crystals. After a few minutes at room temperature to ensure that all crystals were dissolved, the plates were read on an automated microplate reader and the absorbance values were measured at a wavelength of $570 \mathrm{~nm}[27,28]$.

The percentage of growth inhibition was calculated using the formula:

$$
\% \text { of viability }=\frac{\text { Mean OD Samples } x 100}{\text { Mean OD of control }}
$$

\section{Determination of $\mathrm{IC}_{50}$ values}

$\mathrm{IC}_{50}$ was calculated using a linear regression model by plotting the average percentage viability (triplicates per concentration) against the logarithmic value (base 10) of concentration.

\section{Molecular docking}

To confirm the anticancer activity exhibited by the plant extract, molecular docking study of the isolated ligand was performed with Vascular Endothelial Growth Factor Receptor 2 (VEGFR2, PDB ID: 4AG8) using Discovery studio 2018 [29]. The target and ligand were pre-processed before docking for getting the minimized structures and correct conformers. The C docking module was performed for the analysis of the molecular interactions of the targets with the ligand using charm as a force field [30, 31].

\section{RESULTS AND DISCUSSION}

\section{Isolation and structure elucidation of phytoconstituent}

After a sequence of column chromatography and HPLC analysis (fig. 1) of ethanolic leaf extract of Pothos scandens Linn, the purest fraction was collected and dried in a rotary evaporator. The fraction was then subjected to spectroscopic studies. The GC-MS, FTIR, and NMR spectroscopic data obtained for the isolated compound is shown in fig. (2), fig. (3), and fig. (4), respectively.

Based on the spectral characterization, the following structure is proposed for the isolated compound:<smiles>C=CCCCCCCC(=O)c1cc(O)c(O)cc1C(=O)CCCCC=C</smiles>

Molecular formula- $\mathrm{C}_{22} \mathrm{H}_{30} \mathrm{O}_{4}$

IUPAC name-1,1'-(4,5-dihydroxy benzene-1,2-diyl)bisoct-7-en-1-one Smiles notation- $0 \operatorname{c1cc}(\mathrm{C}(=0) \mathrm{CCCCCC}=\mathrm{C}) \mathrm{c}(\operatorname{cc} 10) \mathrm{C}(=0) \mathrm{CCCCCC}=\mathrm{C}$

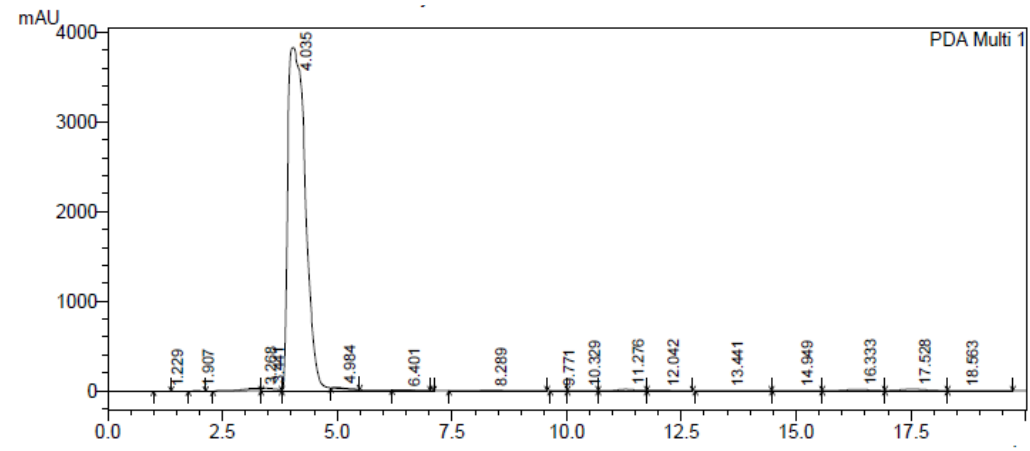

Fig. 1: HPLC of the purest fraction 


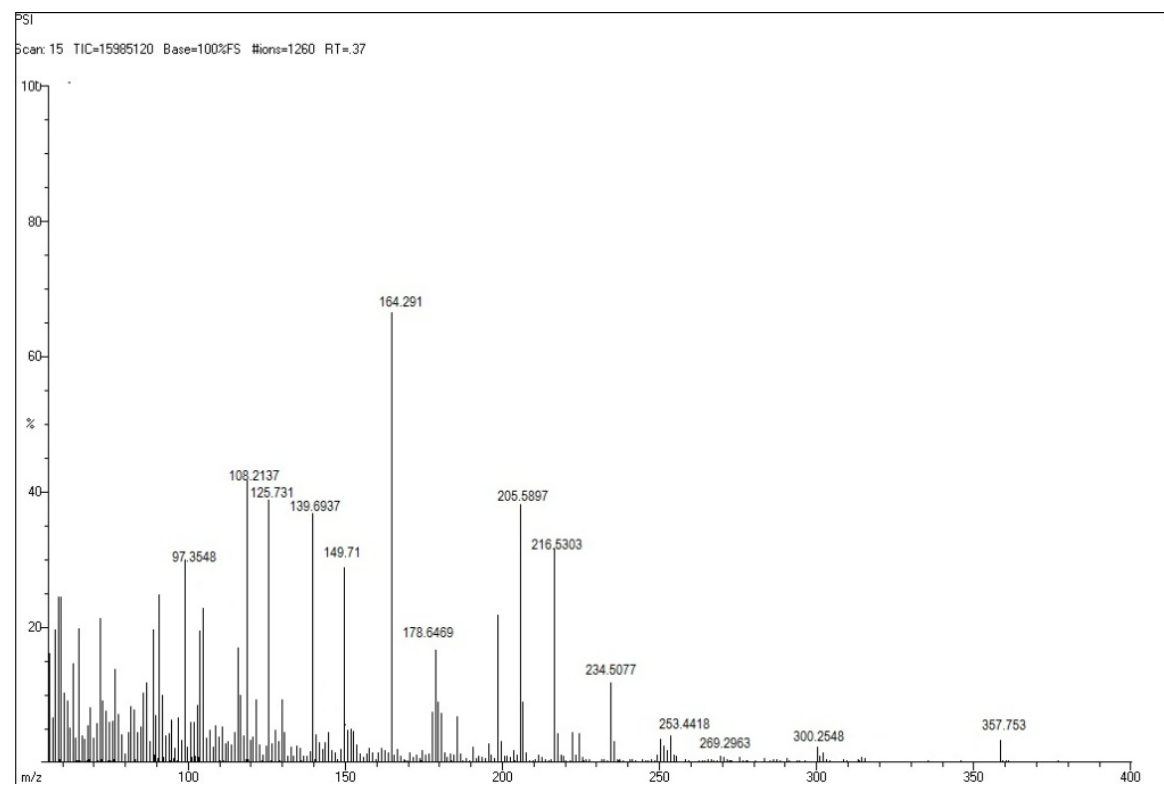

Fig. 2: Mass spectrum of an isolated compound

Table 1: Mass spectral details of the isolated compound

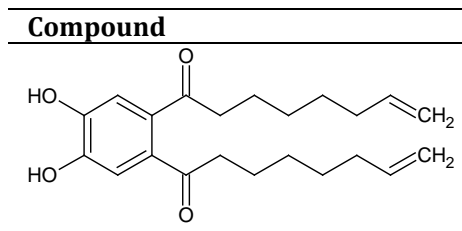

Peak (m/z)
Molecular ion peak at 357.753
Base peak at 164.291

Base peak at 164.291

Peak at 97.3548

Peak at 108.2137

Peak at 125.731

\section{Remarks}

Molecular weight of the isolated compound is 358 Due to the formation of $\mathrm{C}_{8} \mathrm{H}_{4} \mathrm{O}_{4}$ fragment<smiles></smiles>

Due to the formation of $\mathrm{C}_{7} \mathrm{H}_{13}$ fragment $\sim \mathrm{N}_{\mathrm{CH}_{2}}$

Due to the formation of $\mathrm{C}_{6} \mathrm{H}_{4} \mathrm{O}_{2}$ fragment<smiles>Cc1cc(O)c(O)cc1C</smiles>

Due to the formation of $\mathrm{C}_{8} \mathrm{H}_{13} \mathrm{O}$ fragment II

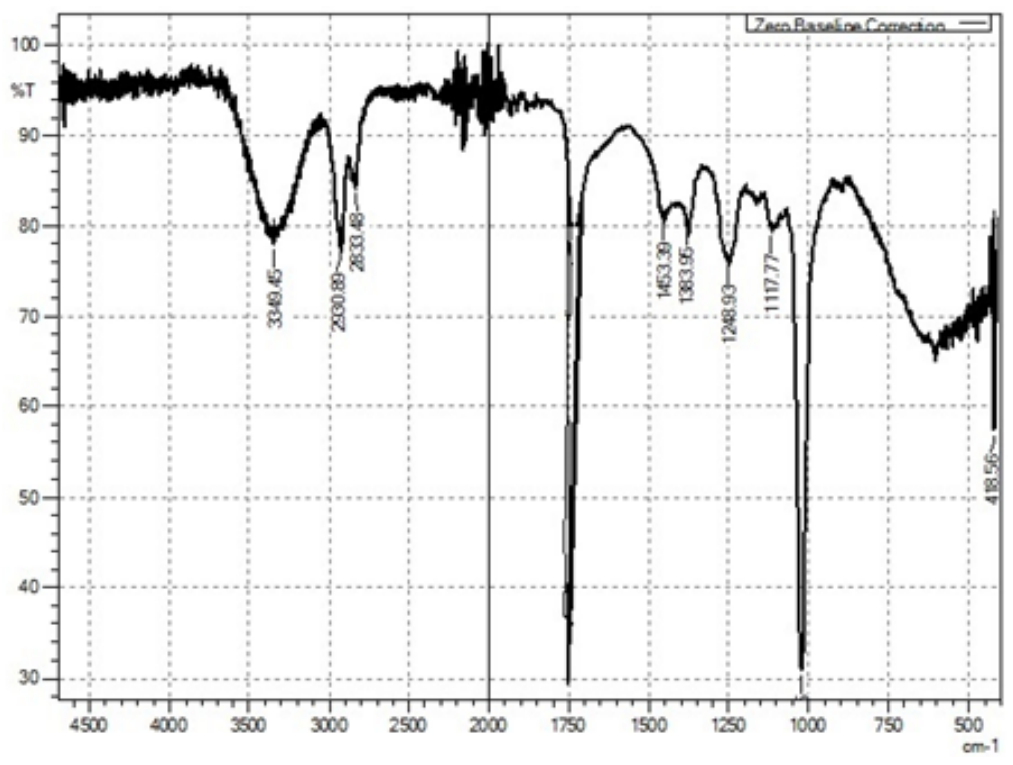

Fig. 3: IR spectrum of an isolated compound 
Table 2: IR spectrum details of the isolated compound

Absorption band (cm-1)
Remarks

F1

PROTON DMSO (E: LLeena) nilst 19

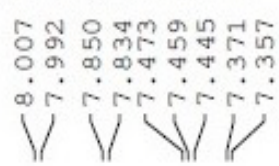

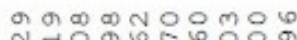

각의

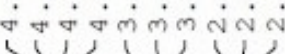

$\begin{array}{lr}\text { Current. Data Parameters } \\ \text { NAME } \\ \text { EXPNO } \\ \text { PROCNO } & 1 \\ & 1\end{array}$

P2 - Acquisition Parameters

Date_ 20180705

Time $\quad 15.27$ h

INSTRUM
PROBHD
z119470 0259

Z119470_0259

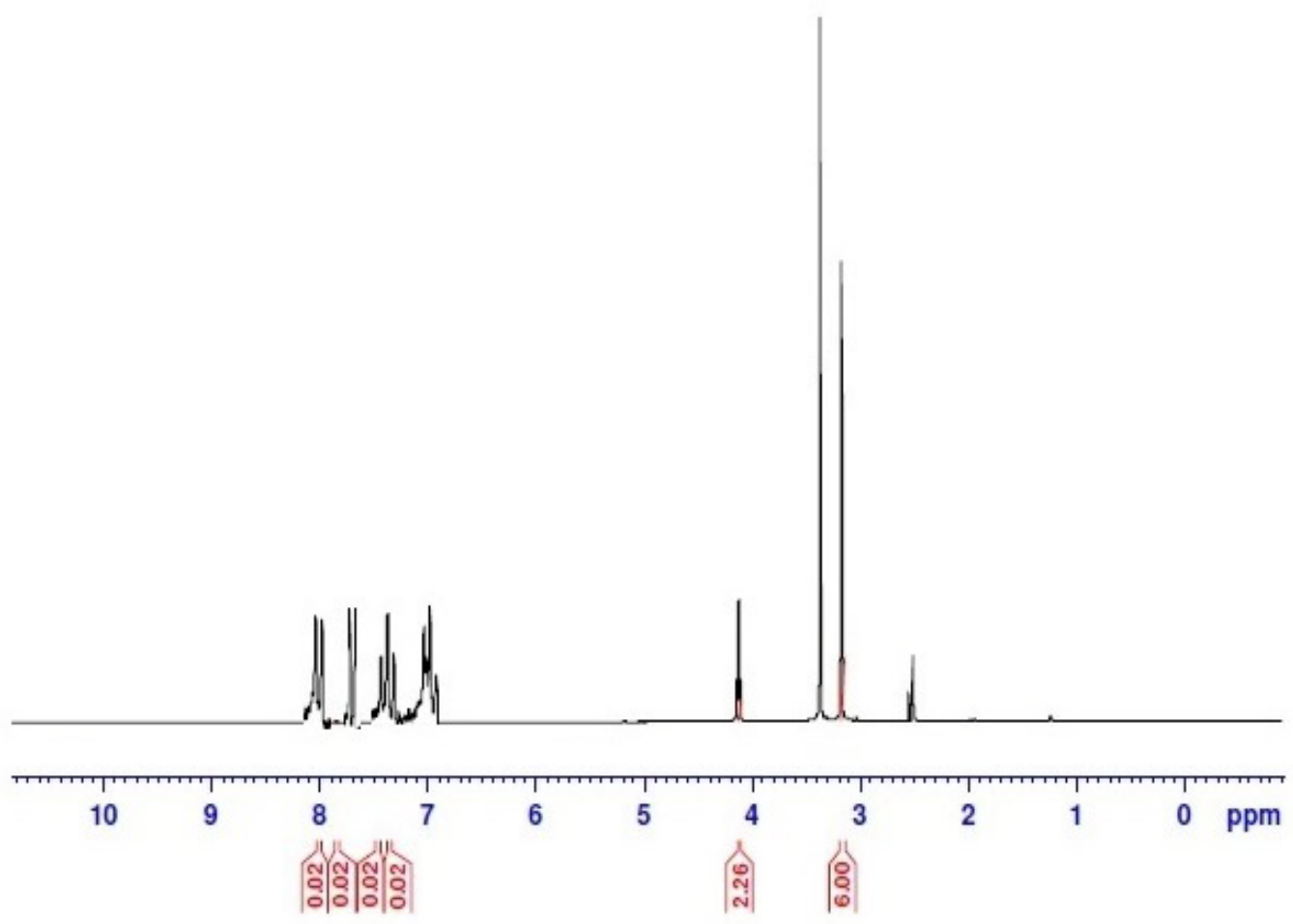

TD

NS

$\begin{array}{lr}\text { SWH } & 10000.000 \mathrm{~Hz} \\ \text { FIDRES } & 0.305176 \mathrm{~Hz}\end{array}$

AQ $\quad 3.2767999 \mathrm{sec}$

RG 77.3.

50.000 usec

$\begin{array}{lr}\mathrm{DE} & 6.50 \mathrm{usec} \\ \mathrm{TE} & 295.0 \mathrm{~K} \\ \mathrm{D} 1 & 1.00000000 \mathrm{sec}\end{array}$

D1 1.00000000 see

SFO1 $500.2330889 \mathrm{MH}$

NUC1 10.000 .233089

$\begin{array}{lr}\text { P1 } & 10.00 \text { use } \\ \text { PLW1 } & 22.69599915 \mathrm{~W}\end{array}$

F2 - Processing purameters

$\begin{array}{lc}\text { P2 - Processing purameters } \\ \text { SI } & 65536 \\ \text { SF } & 500.2300047 \mathrm{MHz} \\ \text { WDN } & \text { EM }\end{array}$

SSB $\quad 0$

LB $0.30 \mathrm{~Hz}$

$\begin{array}{ll}\mathrm{GB} & 0 \\ \mathrm{PC} & 1.00\end{array}$

Fig. 4: NMR spectrum of the isolated compound

Table 3: NMR spectral details of the isolated compound

Chemical shift $\boldsymbol{\delta}$ (ppm)
$\begin{aligned} & \text { Remarks to the proton a } \\ & \text { Due to O-H proton b }\end{aligned}$
$\begin{aligned} & \text { Due to protons 1 } \\ & \text { Due to proton 6 }\end{aligned}$




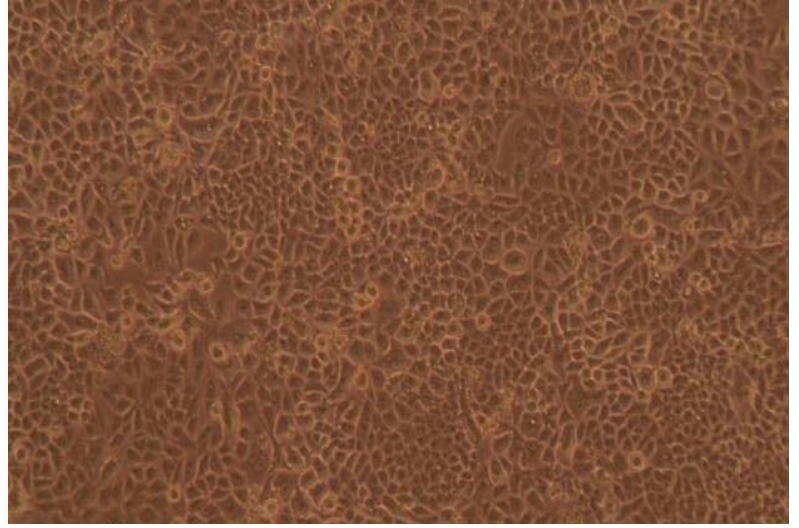

(a)

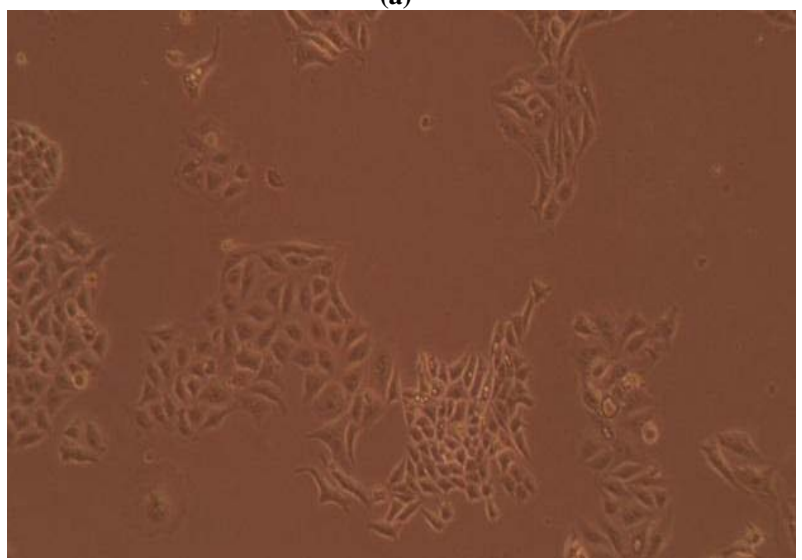

(c)

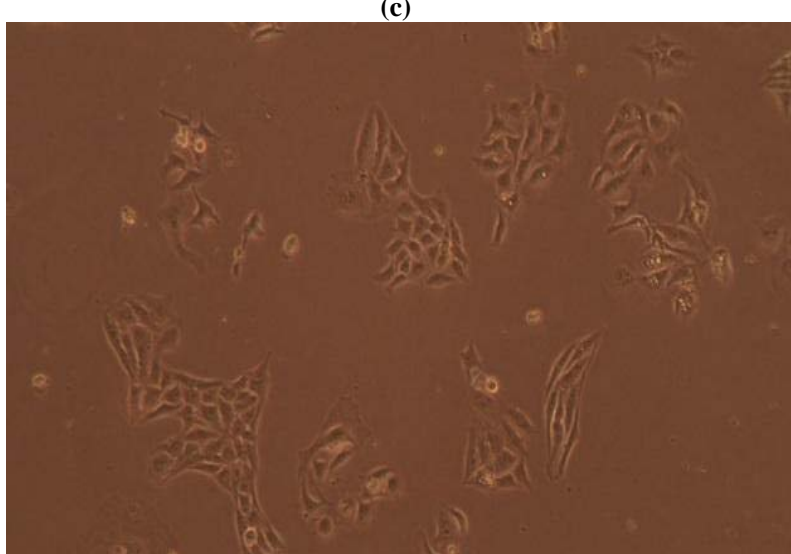

(e)

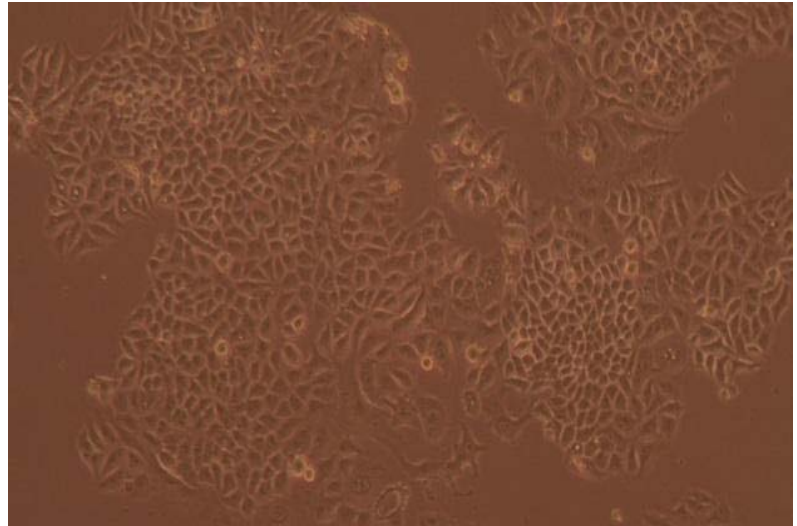

(b)

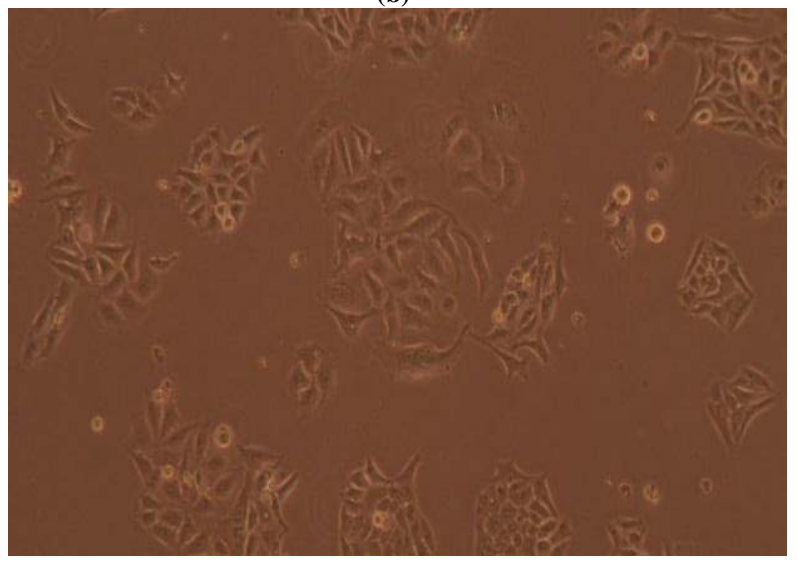

(d)

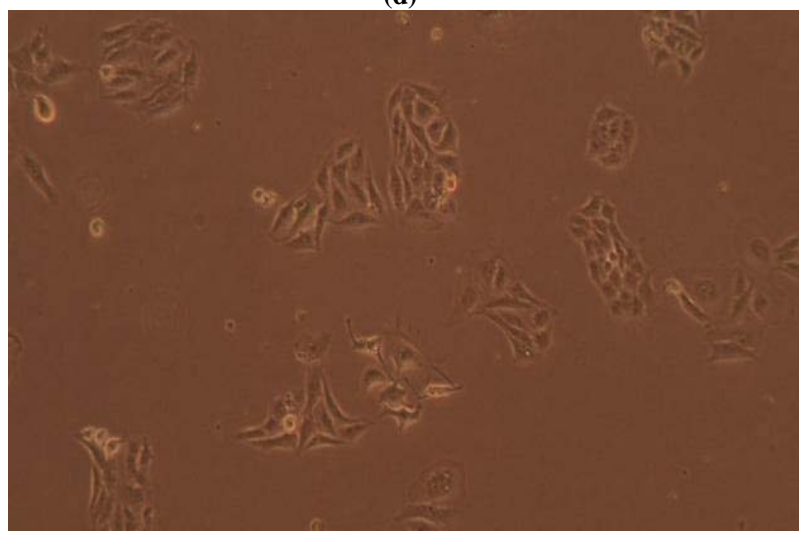

(f)

Fig. 5: Morphological changes showing inhibition of Hela cell lines by different concentrations of ethanolic extract of leaves of Pothos scandens. a: -ve control (95\% ethanol), b: $6.25 \mu \mathrm{g} / \mathrm{ml}$, c: $12.5 \mu \mathrm{g} / \mathrm{ml}, \mathrm{d}: 25 \mu \mathrm{g} / \mathrm{ml}$, e: $50 \mu \mathrm{g} / \mathrm{ml} \mathrm{f:} 100 \mu \mathrm{g} / \mathrm{ml}$

\section{In vitro anti-cancer activity}

In vitro anticancer actiivity of ethanolic extract of leaves of Pothos scandens Linn. was evaluated against HeLa and MCF 7 cell lines. The viability of cells was evaluated by direct observation of cells by an Inverted phase contrast microscope and MTT assay method. The morphological changes in HeLa and MCF 7 cells after treatment with the extract and standard doxorubicin are shown in fig. 5, 6, 7 and 8. The $\mathrm{IC}_{50}$ values are shown in table 4 .

According to the American National Cancer Institute (NCI), crude extracts with an IC $50<30 \mu \mathrm{g} / \mathrm{ml}$ are considered to be active against cancer cells [32, 33]. Different concentrations of the ethanolic extract of leaves of Pothos scandens Linn. exhibited potent cytotoxic activity against HeLa and MCF 7 cell lines with $\mathrm{IC}_{50}$ of 22.9 and 18.32 $\mu \mathrm{g} / \mathrm{ml}$, respectively.

\section{Molecular docking}

The crystal structure of VEGFR2 kinase domain of human with PDB ID: 4AG8 was retrieved from PDB with a resolution of $1.95 \mathrm{~A}^{\circ}$. The protein consists of a single polypeptide chain with a sequence length of 316 amino acids. The binding site of protein interaction with its inhibitor compound Axitinib is Glu917, Cys919 and Asp1046. The preliminary docking analysis was conducted by selecting Glu917, Cys919 and Asp1046 as binding site residues. The ligand selected interacted with ALA 86, VAL 914, ASP 1046 and CYS 1045 with strong H-bond interaction. The docking score, binding energy, Hydrogen bonds, and active site residues of the target protein are shown in table 5. 


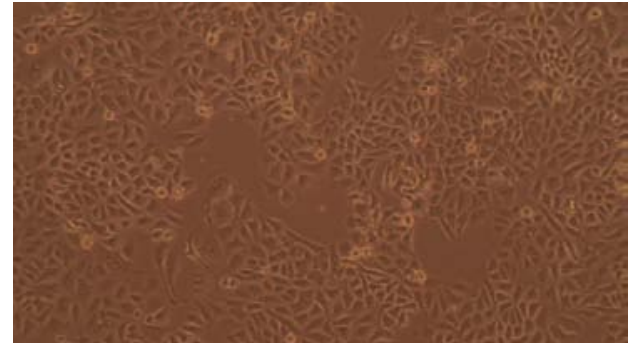

(a)

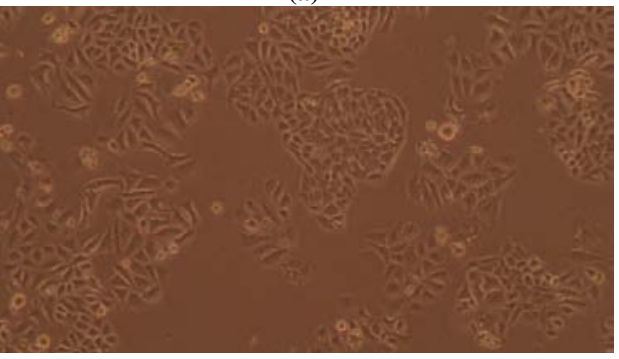

(c)

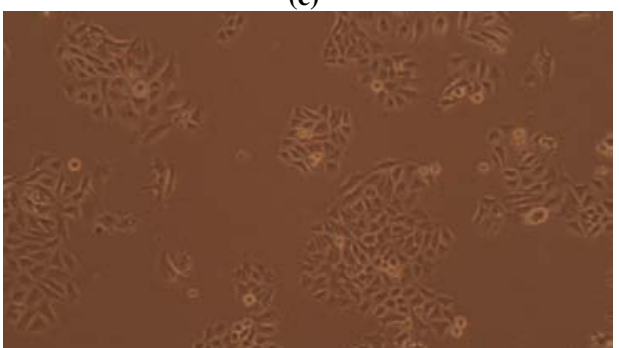

(e)

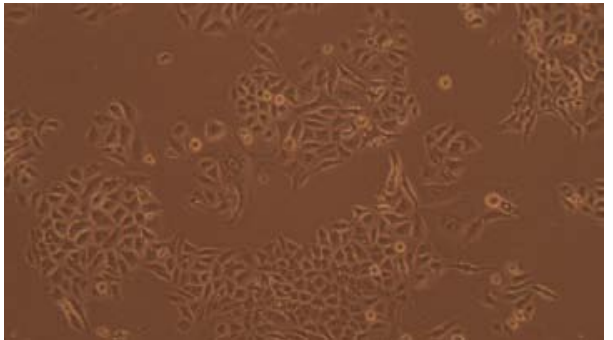

(b)

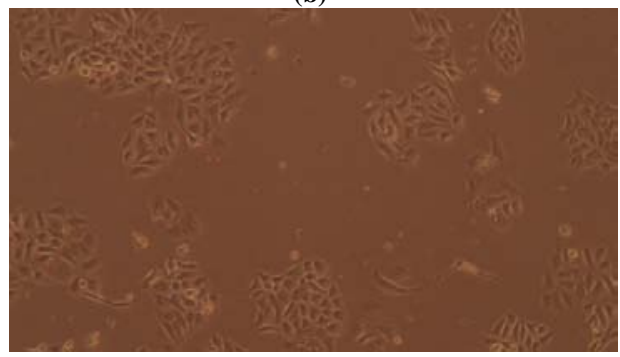

(d)

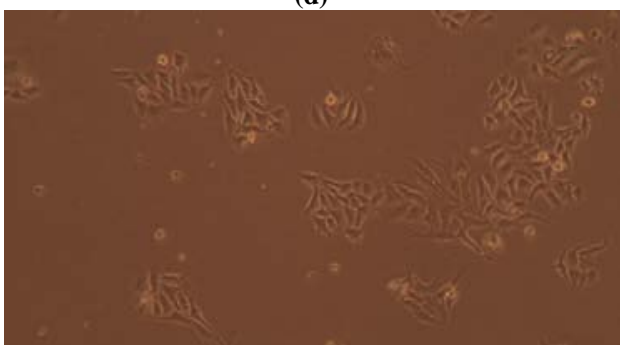

(f)

Fig. 6: Morphological changes showing inhibition of Hela cell lines by different concentrations of standard drug Doxorubicin. a: -ve control (95\% ethanol), b: $0.097 \mu \mathrm{g} / \mathrm{ml}$, c: $0.19 \mu \mathrm{g} / \mathrm{ml}, \mathrm{d}: 0.39 \mu \mathrm{g} / \mathrm{ml}$, e: $0.78 \mu \mathrm{g} / \mathrm{ml}$ f: $1.56 \mu \mathrm{g} / \mathrm{ml}$

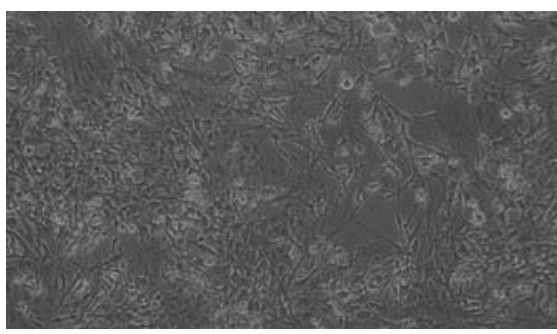

(a)

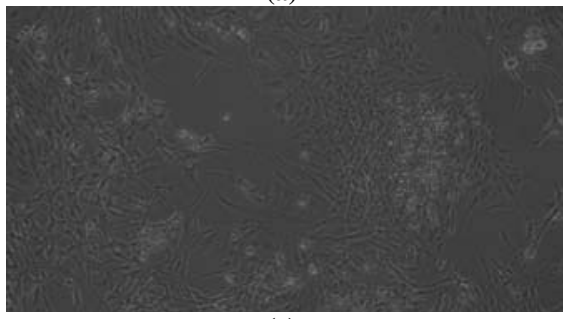

(c)

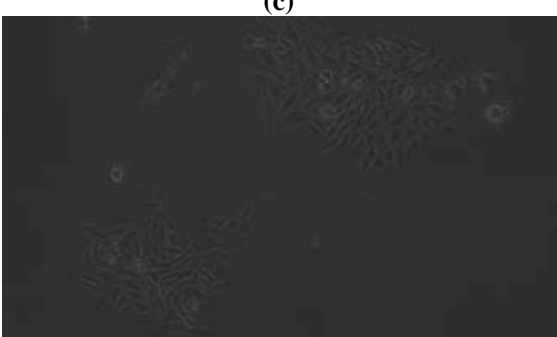

(e)

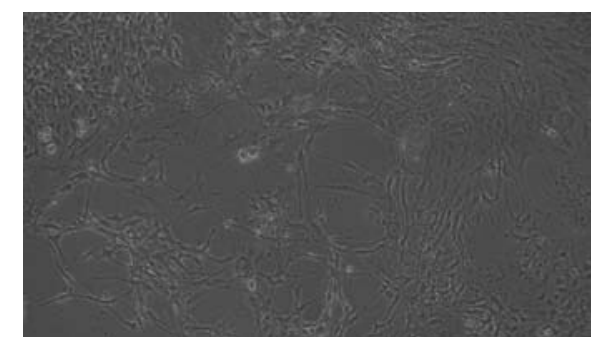

(b)

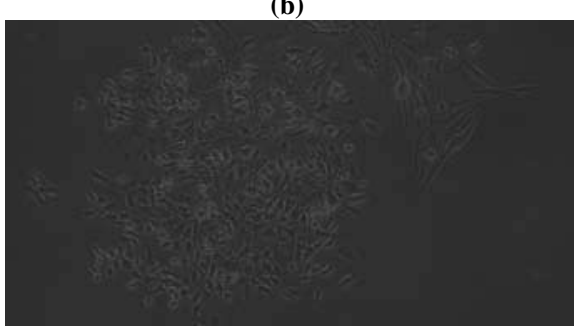

(d)

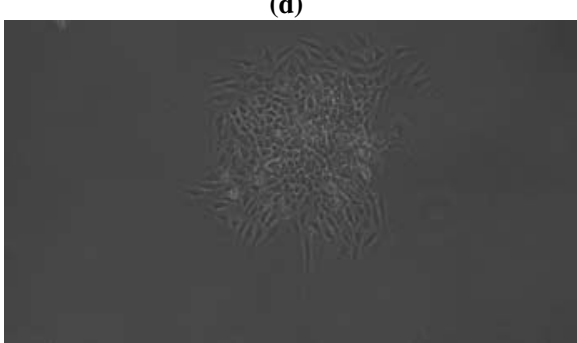

(f)

Fig. 7: Morphological changes showing inhibition of MCF 7 cell lines by different concentrations of ethanolic extract of leaves of Pothos scandens. a: -ve control ( $95 \%$ ethanol), b: $6.25 \mu \mathrm{g} / \mathrm{ml}$, c: $12.5 \mu \mathrm{g} / \mathrm{ml}, \mathrm{d}: 25 \mu \mathrm{g} / \mathrm{ml}$, e: $50 \mu \mathrm{g} / \mathrm{ml}$ f: $100 \mu \mathrm{g} / \mathrm{ml}$ 


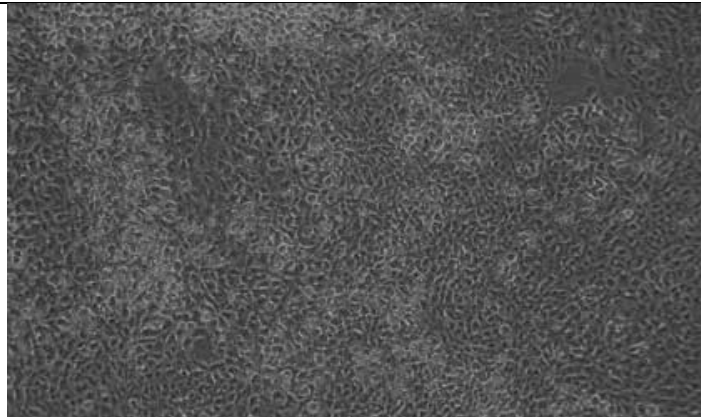

(a)

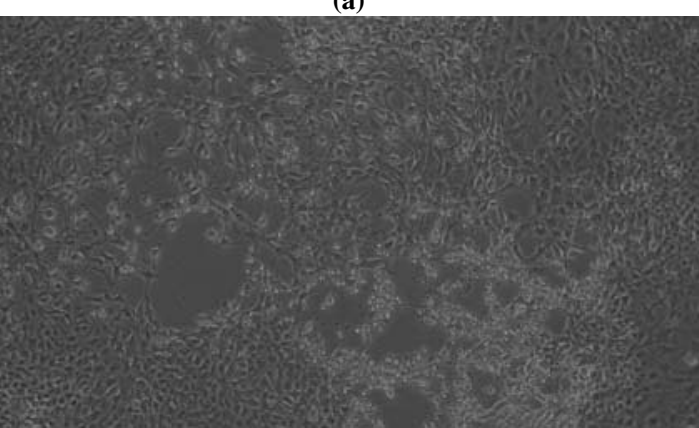

(c)

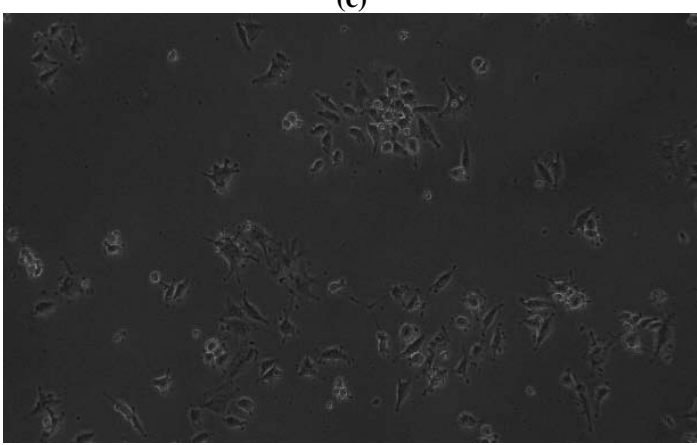

(e)

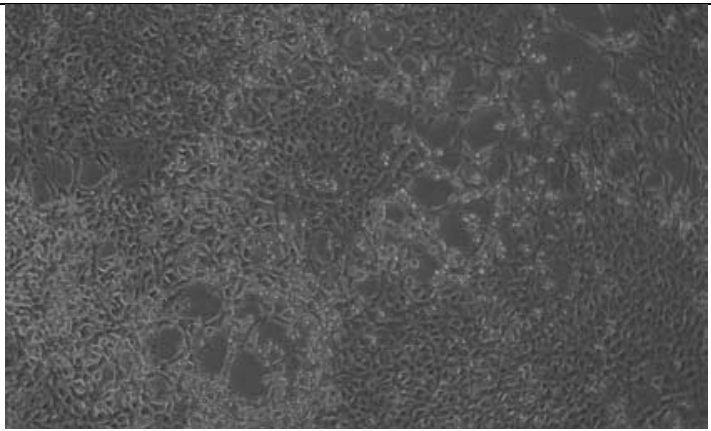

(b)

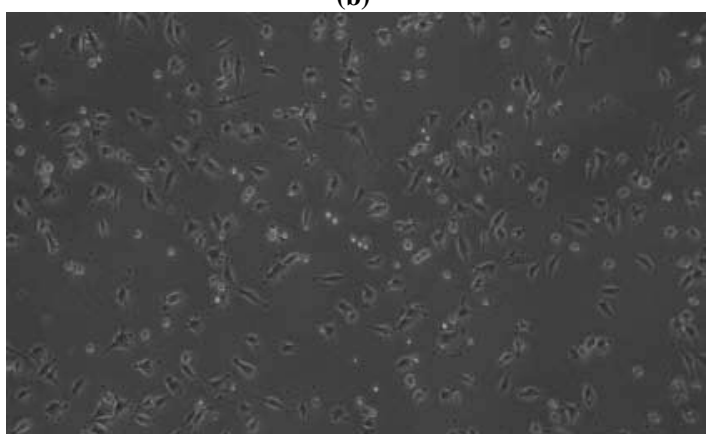

(d)

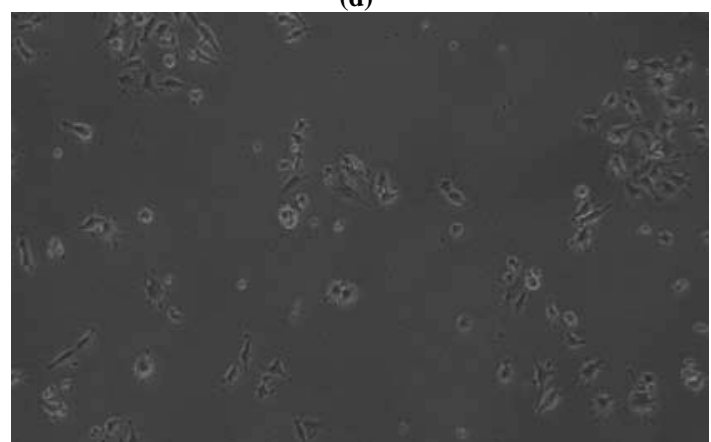

(f)

Fig. 8: Morphological changes showing inhibition of MCF 7 cell lines by different concentrations of standard drug Doxorubicin. a: -ve control ( $95 \%$ ethanol), b: $0.097 \mu \mathrm{g} / \mathrm{ml}$, c: $0.19 \mu \mathrm{g} / \mathrm{ml}, \mathrm{d}: 0.39 \mu \mathrm{g} / \mathrm{ml}$, e: $0.78 \mu \mathrm{g} / \mathrm{ml} \mathrm{f:} 1.56 \mu \mathrm{g} / \mathrm{ml}$

Table 4: IC 50 values of ethanolic leaf extract of Pothos Scandens linn. and doxorubicin on MCF 7 and HeLa cell lines

\begin{tabular}{|c|c|c|c|c|}
\hline Sample & Conc: $(\mu \mathrm{g} / \mathrm{ml})$ & Average asorbance & Percentage viability & $\mathrm{IC}_{50}(\mu \mathrm{g} / \mathrm{ml})$ \\
\hline Ethanolic Leaf Extract (MCF 7 Cell & Control & 0.937 & 100 & 18.32 \\
\hline \multirow[t]{5}{*}{ Line) } & 6.25 & 0.692 & 73.888 & \\
\hline & 12.5 & 0.508 & 54.18 & \\
\hline & 25 & 0.439 & 46.887 & \\
\hline & 50 & 0.247 & 26.396 & \\
\hline & 100 & 14.941 & 16.88 & \\
\hline \multirow[t]{6}{*}{ Doxorubicin (MCF 7 Cell Line) } & Control & 0.931 & 100 & 0.541 \\
\hline & 0.097 & 0.859 & 92.231 & \\
\hline & 0.19 & 0.803 & 86.251 & \\
\hline & 0.39 & 0.637 & 68.457 & \\
\hline & 0.78 & 0.326 & 35.016 & \\
\hline & 1.56 & 0.156 & 16.756 & \\
\hline Ethanolic Leaf Extract (HeLa Cell & Control & 0.745 & 100 & 22.9 \\
\hline \multirow[t]{5}{*}{ Line) } & 6.25 & 0.637 & 85.51 & \\
\hline & 12.5 & 0.53 & 71.109 & \\
\hline & 25 & 0.3 & 40.295 & \\
\hline & 50 & 0.211 & 28.265 & \\
\hline & 100 & 0.107 & 14.356 & \\
\hline \multirow[t]{6}{*}{ Doxorubicin (HeLa Cell Line) } & Control & 1.056 & 100 & 0.93 \\
\hline & 0.097 & 0.9 & 85.288 & \\
\hline & 0.19 & 0.784 & 74.293 & \\
\hline & 0.39 & 0.69 & 65.359 & \\
\hline & 0.78 & 0.562 & 53.192 & \\
\hline & 1.56 & 0.432 & 40.887 & \\
\hline
\end{tabular}



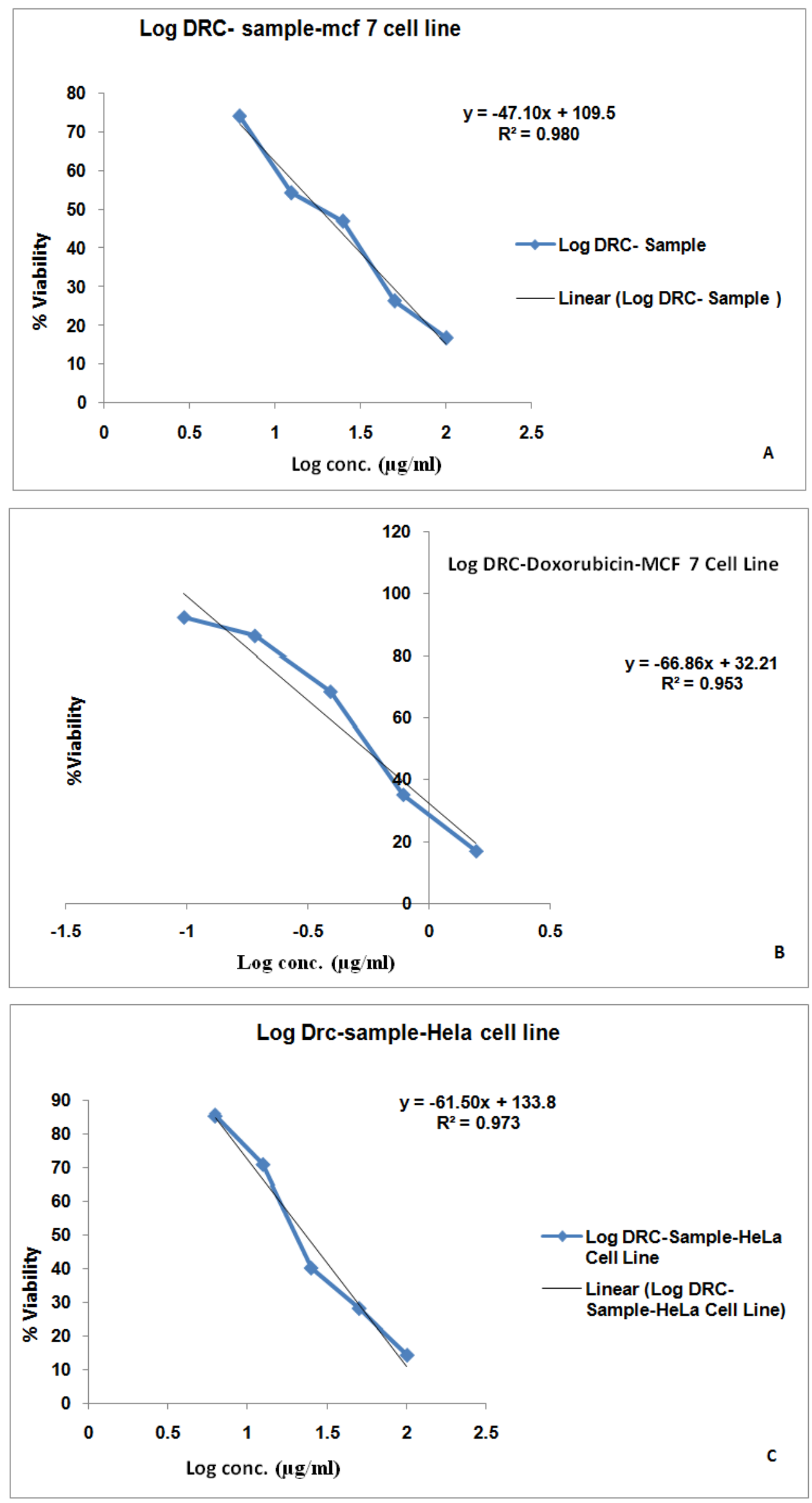


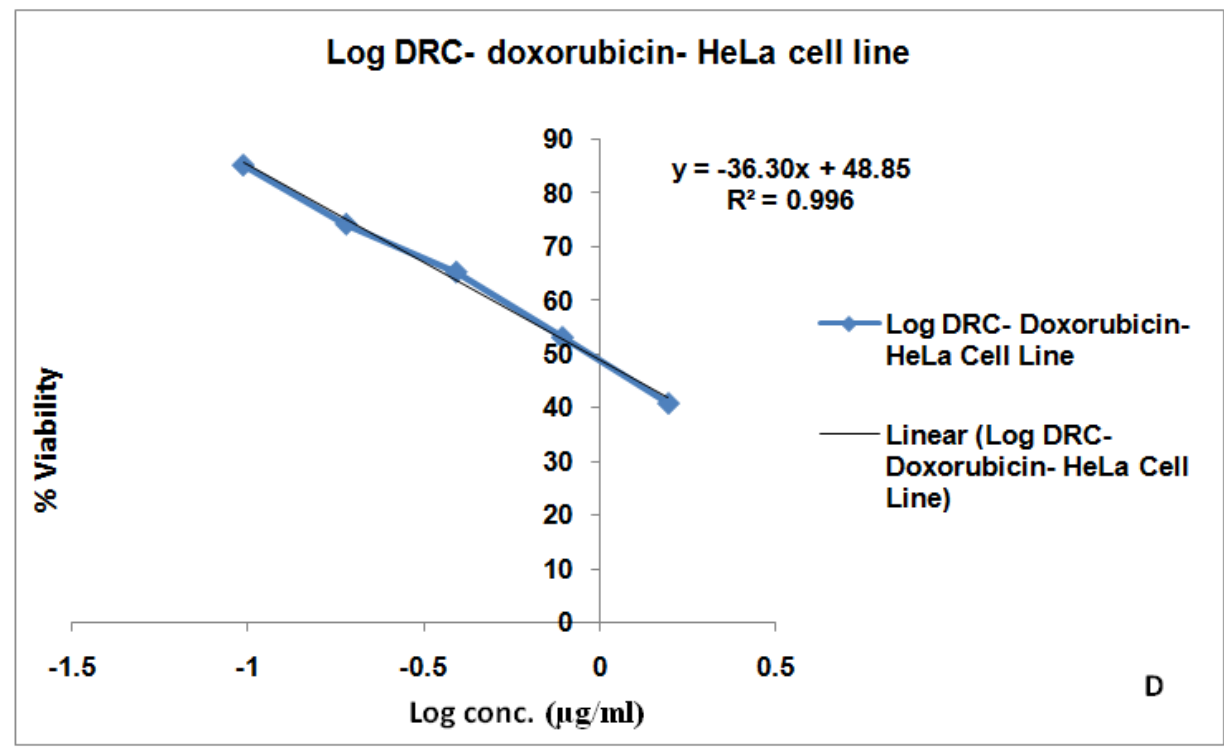

Fig. 9: Log dose-response curve of ethanolic leaf extract of Pothos scandens linn. and doxorubicin, A and B: $\log$ DRC of the extract and doxorubicin in MCF 7 cell lines, C and D: log DRC of the extract and doxorubicin in HeLa cell lines

Table 5: Docking result

\begin{tabular}{|c|c|c|c|c|c|}
\hline $\begin{array}{l}\text { Target protein } \\
\text { PDB ID }\end{array}$ & Ligand selected & $\begin{array}{l}\text { C dock } \\
\text { score }\end{array}$ & $\begin{array}{l}\text { C docker interaction } \\
\text { energy }\end{array}$ & H-bond interaction & Active site residues \\
\hline 4AG8 & & 39.9993 & 61.1657 & Cys1045,Asp1046,Val914,Ala866 & $\begin{array}{l}\text { Glu917,Cys919 } \\
\text { Asp1046 }\end{array}$ \\
\hline
\end{tabular}

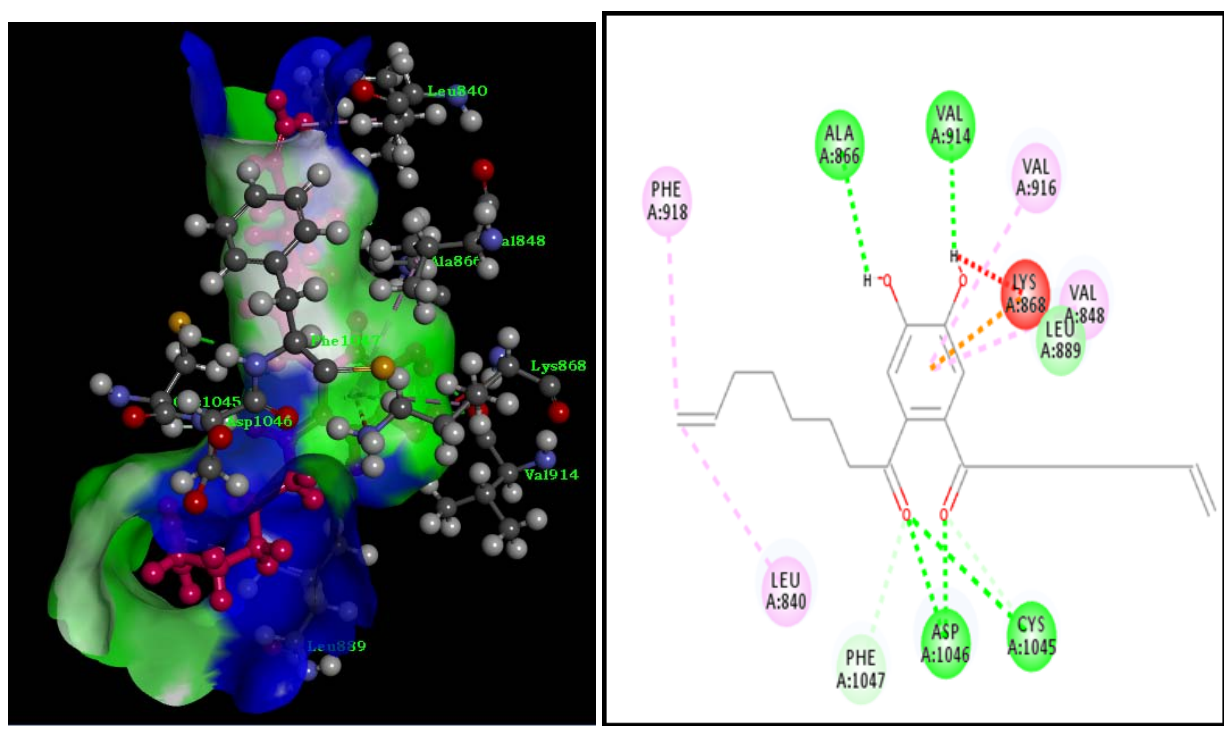

Fig. 10: Docked pose of the selected ligand with the target protein

\section{CONCLUSION}

A phytoconstituent 1,1'-(4,5-dihydroxy benzene-1,2-diyl)bisoct7-en-1-one was isolated from ethanolic leaf extract of Pothos scandens Linn and its structure was elucidated with the help of spectral data. The in vitro anticancer activity of the extract was evaluated using HeLa and MCF 7 cell lines. The findings of the study revealed that the extract is cytotoxic against the selected cell lines. The anticancer potential of the plant was further confirmed by molecular docking studies. The docking score showed that the isolated compound interacted strongly with 4AG8. The study suggests that Pothos scandens Linn. can be used for the isolation of potent anticancer agents. Detailed in vivo studies are required for further validation.

\section{ACKNOWLEDGEMENT}

The authors extend their sincere gratitude to Dr. Mathew Dan, Senior scientist, JNTBGRI, Palode, Kerala and Dr. G. Valsaladevi, Curator, Department of Botany, the University of Kerala for their help in the collection and identification of plant samples.

We are also thankful to R and D lab, Athmic Biotech Solutions for providing laboratory facilities for in vitro studies. 


\section{FUNDING}

Nil

\section{AUTHORS CONTRIBUTIONS}

All the authors have contributed equally.

\section{CONFLICT OF INTERESTS}

The authors do not have any conflict of interest.

\section{REFERENCES}

1. RS Sathoskar, SD Bhandarkar, SS Ainapure. Pharmacology and pharmacotherapeutics. 17t ed. Mumbai: Popular Prakashan; 2001. p. 800-1.

2. Alfarouk KO, Stock CM, Taylor S, Walsh M, Muddathir AK, Verduzco D. Resistance to cancer chemotherapy-failure in drug response from ADME to P-gp. Cancer Cell Int 2015;15:71.

3. Javed Iqbal, Banzeer Ahsan Abbasi, Tariq Mahmood, Sobia Kanwal, Barkat Ali, Sayed Afzal Shah, Ali Talha Khalil. Plantderived anticancer agents-a green anticancer approach. Asian Pac J Trop Biomed 2017;7:1129-50.

4. Abdul Wahab Siti Mariam, Jantan Ibrahim, Haque Md Areeful, Arshad Laiba. Exploring the leaves of annona muricata L. as a source of potential anti-inflammatory and anticancer agents. Front Pharmacol 2018;9:661.

5. Thakore P, Mani RK, Kavitha SJ. A brief review of plants having anti-cancer property. Int J Pharm Res Dev 2012;3:129-36.

6. Tariq A, Sadia S, Pan K, Ullah S, Mussarat F. A systematic review on ethnomedicines of anti-cancer plants. Phytother Res 2017;31:202-64.

7. Li-Rui Sun, Wei Zhou, Hong-Mei Zhang, Qiu-Shi Guo, Wei Yang, Bing-Jin Li, et al. Modulation of multiple signaling pathways of the plant-derived natural products in cancer. Front Oncol 2019;9:1153.

8. Mansor M, Boyce PC, Othman AS, Sulaiman B. The araceae of peninsular Malaysia, Penerbit USM; 2012. p. 1-146.

9. DeFilipps RA, Krupnick GA. The medicinal plants of Myanmar. Phytokeys 2018;102:1-341.

10. Das AK, Dutta BK, Sharma GD. Medicinal plants used by different tribes of Cachar district, Assam. IJTK 2008;7:446-54.

11. Niral H, Sojeetra, Rabinarayan Acharya A. Review on ethnomedicinal claims and spread of Pothos scandens L. Eur J Med Plants 2020;31:22-8.

12. Santhosh Kumar JU, Krishna Chaitanya MJ, Andrew J Semotiuk, Krishna V. Indigenous knowledge on medicinal plants used by ethnic communities of South India. Ethnobot Res Appl 2019;18:1-112.

13. Savinaya MS, Patil SS, Narayana J, Krishna V. Traditional medicine knowledge and diversity of medicinal plants in sharavathi valley region of central-western ghats. Int J Herb Med 2016;4:124-30.

14. Ayyanar M, Ignacimuthu S. Traditional knowledge of kani tribals in kouthalai of tirunelveli hills, Tamil Nadu, India. J Ethnopharmacol 2005;102:246-55.

15. Inta A, Shengji $P$, Balslev H, Wangpakapattanawong $P$, Trisonthi C. A comparative study on medicinal plants used in Akha's traditional medicine in China and Thailand, cultural coherence or ecological divergence. J Ethnopharmacol 2008;116;508-17.

16. Kamal HM, Bidur S, Kaium SMA, Mazumder K. Anti-diabetic and bronchodilator activities of Pothos scandens linn leaves. Int J Pharm Phytochem Res 2015;7:1202-7.
17. Vinayaka KS, Prashith Kekuda TR, Rajkumar N, Chandrasekhar MB. Studies on antibacterial, anthelmintic and larvicidal efficacy of Pothos scandens L. Res J Pharm Technol 2009;2:8503.

18. Thankarajan Sajeesh, Karuppusamy Arunachalam, Tangaraj Parimelazhagan. Antioxidant and antipyretic studies on pothos scandens L. Asian Pac J Trop Med 2011;4:889-99.

19. Harborne JB. Phytochemical methods-a guide to modern techniques of plant analysis. $3^{\text {rd }}$ ed. London: Chapman and Hall; 1984. p. 1-7.

20. Kumar R, Murugananthan G, Nandakumar K, Talwar S. Isolation of anxiolytic principle from ethanolic root extract of Cardiospermum halicacabum. Phytomedicine 2011;18:219-23.

21. Shanmugam Prakash, Nagaraj Elavarasan, Kasivisvanathan Subashini, Selvaraj Kanaga, Ramamurthy Dhandapani, Magudeeswaran Sivanandam, et al. Isolation of hesperetin-a flavonoid from Cordia sebestena flower extract through antioxidant assay guided method and its antibacterial, anticancer effect on cervical cancer via in vitro and in silico molecular docking studies. J Mol Struct 2020;1207:1-13.

22. Wan Mohd Zain WN, Rahmat A, Othman F, Yap TY. Antiproliferative properties of clausine-b against cancer cell lines. Malays J Med Sci 2009;16:29-34.

23. Mosmann T. Rapid colorimetric assay for cellular growth and survival-application to proliferation and cytotoxicity assays. J Immunol Methods 1983;65:55-63.

24. Ferrari M, Fornasiero MC, Isetta AM. MTT colorimetric assay for testing macrophage cytotoxic activity in vitro. J Immunol Methods 1990;131:165-72.

25. Himali Somaweera, Gary C, Lai, Rachel Blackeye, Beverly Littlejohn, Justine Kirksey, et al. Ethanolic extracts of california mugwort (Artemisia douglasiana Besser) are cytotoxic against normal and cancerous human cells. J Herb Med 2013;3:47-51.

26. Asadollahi M, Firuzi O, Heidary Jamebozorgi F, Alizadeh M, Jassbi AR. Ethnopharmacological studies, chemical composition, antibacterial and cytotoxic activities of essential oils of eleven salvia in Iran. J Herb Med 2018;20:100-250.

27. Barile FA. Continuous cell lines as a model for drug toxicity assessment. In: Jose Castell, Maria Gmez-Lechn. (Eds.) In vitro methods in pharmaceutical research. E-Publishing Inc. London: Academic Press; 1997. p. 33-54.

28. AL-Zuaidy MH, Ismail A, Mohamed S, Razis AFA, Mumtaz MW, Hamid AA. Antioxidant effect, glucose uptake activity in cell lines and cytotoxic potential of Melicope Lunu-Ankenda leaf extract. J Herb Med 2018;14:55-60.

29. McTigue M, Murray BW, Chen JH, Deng YL, Solowiej J, Kania RS. Molecular conformations, interactions, and properties associated with drug efficiency and clinical performance among VEGFR TK inhibitors. PNAS 2012;109:18281-9.

30. Roy K, Kar S, Das RN. Understanding the basics of QSAR for applications in pharmaceutical sciences and risk assessment. I ${ }^{\text {st }}$ ed. London: Academic Press; 2015. p. 357-425.

31. Kaloni D, Chakraborty D, Tiwari A, Biswas S. In silico studies on the phytochemical components of Murraya koenigii targeting TNF- $\alpha$ in rheumatoid arthritis. J Herb Med 2020;24:100396.

32. Suffnes M, Pezzuto JM. Assays related to cancer drug discovery. In: Hostettmann K. (Ed.) Methods in Plant Biochemistry: Assays for Bioactivity. Vol. 6. London: Academic Press; 1990. p. 71-133.

33. Itharat A, Houghton PJ, Eno-Amooquaye E, Burke PJ, Sampson JH, Raman A. In vitro cytotoxic activity of Thai medicinal plants used traditionally to treat cancer. J Ethnopharmacol 2004;90:33-8. 